\title{
Fragmentaiom operation in left atrium for correction of isolated mitral valve disease
}

\author{
Pukas K. V., Leoshko I. V.
}

\author{
Amosov National Institute of Cardiovascular Surgery Academy of Medical Sciences of Ukraine
}

\begin{abstract}
Aim of investigation is to research possibilities of intraoperative renewal of sinus rhythm by proposed method during mitral valve replacement (MVR).

In analyzed group are included 161 patients with isolated mitral valve disease in IV stage who were operated in Institute. In 155 patients underwent MVR and 6 mitral valve`s plasty with operation Labyrinth. Plasty of left atrium (LA) was performed in $119(79,3 \%)$ patients for prevention spread of re-entry waves. Operation of LA's fragmentation (Maze-3,4) was performed in all cases by radio-frequency method (25-30 watt), and also with ligation and resection of LA`s auricle. Among 161 operated patients 3 patients died on a hospital stage. Renewal of sinus rhythm in group pts with LA's plasty was in $86,7 \%$, than is higher than in alternative group $(64,5 \%(\mathrm{p}<0,05))$.

MVR with operation Maze allows successfully renew sinus rhythm on a hospital stage and stabilize it well during half-year after operation.
\end{abstract}

Key words: mitral valve disease, arrhythmia, surgical rhythm's renewal, cardio-pulmonary bypass.

Aim of investigation is to research possibilities of intraoperative renewal of sinus rhythm by proposed method during correction of mitral valve diseaese.

In analyzed group are included 161 patients with isolated mitral valve disease in IV stage who were operated in Institute. Plastic LA performed in 119 (78.9\%) patients in order to reduce it and to prevent propagation wave of re-entry. Fragmentation in the LA was held in low radiofrequency mode (25-35 watts) for option transactions left Maze-3,4. Of the 161 patients operated on at the hospital stage 3 patients died (hospital mortality 1.9\%). Mitral valve replacement combined with maze low radiofrequency mode allows you successfully restore proper rhythm in $80.2 \%$ of cases during hospital stay and stabilize it for six months after surgery.

Material and methods. Analyzed group consisted of 161 patients with isolated mitral valve disease IV were on the surgical treatment in the Department of Surgery of acquired heart of the National Institute of Cardiovascular Surgery Academy of Medical Sciences of Ukraine since January 1, 2009 to January 1,2014 . The men were $59(36,6 \%)$, women $-102(63,4 \%)$. The age of patients ranged from 39 to 70 years (mean 57,3 $\pm 6,2$ years). 39 (24.2\%) patients were belong in a class III classification NYHA, $122(75.8 \%)$ patients class IV. The leading etiology was rheumatic defects. Calcification of the mitral valve was observed in 49 (30.4\%) patients. The average duration of the existence of atrial fibrillation was $3,0 \pm 0,4$ years.

Fragmenting procedure in the LA in all patients was carried out by low radiofrequency (25-35 watts in the coagulation mode) ablation of the left atrium of the embodi- ment operations left the Labyrinth (Maze-3,4). Fragmentation is a prerequisite ligation and resection of the outsid auriculum of LA. All operations were performed by a single surgeon as unique methodology - the developer of methodologies (V. V. Popov). When dilatation was performed additionally LA its reduction in $119(72,4 \%)$ patients. Reduction techniques presented LA paraannuly plication back wall of LA (62 patients) the triangular plastic of LA (patient 47$)$ and arch plasty $(n=10)$ to reduce the size of LA at least $5.0 \mathrm{~cm}$ and to prevent propagation re-entry due to creation of scar zones LA. The indication for the reduction of LA in combination with the fragmenting procedure was the size of the LA $5.0 \mathrm{~cm}$ or more. The original size of the LA was $61,5 \pm 1,5 \mathrm{~mm}$. All patients were performed MVR: 1) saving the posterior leaflet of MV (114 patients), 2) saving the posterior leaflet of $\mathrm{MV}+$ translocation of the papillary muscles of the front flap cut in the fibrous ring of the left atrioventricular ring (39 patients), 3) with complete retention of both mitral valve ( 2 patients).

All operations were performed under cardiopulmonary bypass and moderate hypothermia $\left(33-34^{\circ} \mathrm{C}\right)$. Myocardial protection was carried out under conditions of retrograde cardioplegia solution custodiol in combination with external cooling. Access to mitral valve was through the LA position and parallel to the diatrial groove. Used for implantation in the mitral position of the bicuispid valve prostheses Saint Jude. Fixation of prostheses to hold separate P-shaped sutures with teflon liners in the amount of 14-19 in an intermediate position.

In order to keep the proper rhythm medication during surgery following criteria are met: 1) the level of plas- 
matic potassium maintained in post perfusion period of $4.5 \mathrm{mmol} / \mathrm{L}$ or greater, 2) for the period of operation was introduced $20-30 \mathrm{ml}$ of $25 \%$ magnesium sulfate at the rate of $0.25 \mathrm{ml} / \mathrm{kg}, 3$ ) in the postoperative period excludes the use of diuretics, potassium excretory, 4) the value of hematocrit at the end of perfusion was 0.3 and above, to exclude significant hemodynamic failure, and fluid balance by not more than $+500,0-700,0 \mathrm{ml}, 5$ ) administering cordarone during operation period within $300 \mathrm{mg}$ on subsequent days - daily dose in the range 300-600 $\mathrm{mg}$, 6) panangine application within a period of $20-30 \mathrm{ml}$ per operation.

Aortic cross-clamping time was $75,2 \pm 8,1 \mathrm{~min}$. Hemorrhage noted within $400.0 \mathrm{ml}$, allowing in $101(62,7 \%)$ cases eliminate the use of blood and its components throughout the hospital stay. Complications during hospital stay associated with the procedure of the operation were observed.

Results and discussion. Of the 161 patients operated on at the hospital stage 3 deaths (1.9\% hospital mortality). The causes of deaths: pneumonia and multi-organ failure. Inotropic support (dobutamine) was within 3-4 mkrg/ $\mathrm{kg} /$ min. during the first 56 hours. Time on mechanical ventilation was $8,2 \pm 1,5$ hours and in the intensive care unit $57,4 \pm 3,5$ hours. Dynamics of echocardiography parameters during the treatment were: left ventricular ejection fraction $-0,56 \pm 0,03$ (before surgery) and 0,58 $\pm 0,02$ (after surgery), the diameter of the LP (mm) $-61,5 \pm 1,5$ ( before surgery) and 49,1 $\pm 1,7$ (after surgery). Sinus rhythm was restored immediately after the removal of the clamp from the aorta in $132(81.7 \%)$ patients, and discharge ECG was observed in $130(80.2 \%)$. At 11,1 $\pm 1,2$ days after the operation in the department in $27(17.4 \%)$ cases had to restore rhythm by defibrillation with successful results in $21(77.7 \%)$ cases. At discharge sinus rhythm in patients with plastic LA was higher than in the alternative group: 85,7\% $(n=103 / 119)$, and $64,5 \%(n=27 / 42)(\mathrm{p}<0.05)$.

Conclusions. The presence of arrhythmias in patients with mitral defect reduces the performance of the heart by $38-39 \%[3,4]$. This is especially important in patients with artificial heart valves as the presence of arrhythmias lead not only to progressive heart failure and also creates conditions for thrombosis, embolism that leads to impaired graft function [1-3]. In this regard, it is important to restore the proper rhythm is already in the early postoperative period. That's why do not stop looking for new surgical techniques to restore sinus rhythm, and optimization of intraoperative methods of restoring normal rhythm of the heart, particularly in prosthetic mitral valve (MVP). Mitral valve surgery combined with maze in our modification can successfully restore proper rhythm in $80.6 \%$ of cases at the hospital stage. Applied drug support adequately consolidated efforts together with the original methodology implemented low radiofrequence ablation (scheme Maze-3) to restore sinus rhythm. The proposed method of fragmentation inexpensive. Element of LA reduction is important for the restoration of sinus rhythm. The data obtained nearest distant period allow us to evaluate the capacity of the proposed optimistic technique.

\section{Literature}

1. Henry L., Ad N. The surgical treatment for atrial fibrillation: ablation technology and surgical approaches // Rambam Maimonides Med J. - 2013. - Vol. 4. - e0021.

2. Outcome of concomitant Cox-maze III procedure using argon-based cryosurgical system: a single-center experience with 250 patients / Yanagawa B., Holmes S. D., Henry L. et al. // Ann Thorac Surg. - 2013. - Vol. 95. - P. 1633-9.

3. THE CURE-AF trial: a prospective, multicenter trial of irrigated radio-frequency ablation for the treatment of persistent atrial fibrillation during concomitant cardiac surgery / Damiano R. J., Badhwar V., Acker M. A. et al. // Heart Rhythm. - 2014. - Vol. 11. - P. 39-45.

4. Atrial structure and function and its implications for current and emerging treatments for atrial fibrillation / Prabhu S., McLellan A. J., Walters T. E. et al. // Prog Cardiovasc Dis. - 2015. - Vol. 58. - P. 152-67.

\title{
Операція лабірінт при корекції клапанної вади серця
}

\author{
Пукас К. В., Леошко І. В.
}

ДУ «Національний інститут серцево-судинної хірургії імені М. М. Амосова НАМН України» (Київ)

Метою дослідження є вивчення можливостей запропонованої методики інтраопераційного відновлення синусового ритму при корекції клапанної вади (КВ).

аналізовану групу включений 161 пацієнт з ізольованою мітральною вадою IV стадії, що знаходилися на хірургічному лікуванні в Інституті. У 155 пацієнтів було виконано ПМК в поєднанні з операцією Лабіринт, а в 6 випадках - пластика мітрального клапана. Пластика лівого передсердя (ЛП) виконана у 119 (79,3\%) пацієнтів 3 метою виключення поширення хвиль re-entry. Операція фрагментації ЛП $($ Maze-3,4) виконувалася в усіх пацієнтів радіочастотним методом (25-30 Ватів), а також із лігуванням та резекцією вушка ЛП. 3161 прооперованих пацієнтів на госпітальному етапі померло 3 (1,9\%). Відновлення синусового ритму в групі пацієнтів із пластикою ЛП спостерігалося у 85,7\% випадків, що вище, ніж в альтернативній групі $(64,5 \%(\mathrm{p}<0,05))$.

Протезування мітрального клапана у поєднанні з операцією Лабіринт дозволяє успішно відновити правильний ритм на госпітальному етапі та стабілізувати його впродовж півроку після операції.

Ключові слова: мітральна вада, порушення ритму, хірургічне відновлення правильного ритму, штучний кровообіг. 


\title{
Операция лабиринт при коррекции клапанных пороков сердца
}

\author{
Пукас Е. В., Леошко И. В.
}

ГУ «Национальный институт сердечно-сосудистой хирургии имени Н. М. Амосова НАМН» (Киев)

Целью исследования является изучение возможностей предложенной методики интраоперационного восстановления синусового ритма при коррекции клапанной патологии (КП).

В анализируемую группу включены 161 пациент с клапанной патологией и сопутствующей фибрилляцией предсердий, находившихся на хирургическом лечении в отделении хирургического лечения приобретенных пороков сердца Института. Фрагментация в предсердиях проводилась в низкорадиочастотном режиме (режим диатермии 25-35 Ватт) по варианту операции Maze-3,4 -box (“cut and sew”). Пластика ЛП выполнена у 119 (79,3\%) пациентов с целью его уменьшения ниже 5,0 см. Из 161 оперированных пациентов на госпитальном этапе умерло 6 (госпитальная летальность составила 2,7\%). Коррекция клапанной патологии в сочетании с операцией Лабиринт в низкорадиочастотном режиме (35 Ватт) позволяет успешно восстановить правильный ритм в 79,2\% случаев на госпитальном этапе и стабилизировать его в послеоперационный период.

Ключевые слова: клапанная патология сердиа, нарушения ритма, хирургическое восстановление правильного ритма, искусственное кровообращение. 